\title{
INTEGRATION OF INFORMATION AND COMUNICATION TECHNOLOGY INTO ISLAMIC RELIGIOUS EDUCATION TEACHER TRAINING
}

\author{
Miskiah Miskiah $^{1^{*}}$, Yoyon Suryono $^{2}$, and Ajat Sudrajat ${ }^{3}$ \\ ${ }^{1}$ Palembang Religious Training Center \\ ${ }^{1,2,3}$ Pascasarjana, Universitas Negeri Yogyakarta, Indonesia \\ *e-mail: miskiah78@kemenag.go.id
}

\begin{abstract}
Integrating ICT in teacher training has become an absolute necessity over recent years. This research highlights the role of training as a means to improve Islamic religious education teacher competence in ICT. Specifically, the case-study research aim is to describe the level of ICT integration into the Islamic religious education training, referring to 'education-and-training', at a religious training center (RTC) in Palembang, Indonesia. Thirty teachers of Indonesian Islamic school (madrasah) and two facilitators at the RTC acted as informants in the research. Using the interactive model of qualitative analysis by Miles and Huberman, the research results indicated that the participants have already integrated ICT but were restricted to using presentations, especially the PowerPoint computer program. Secondly, age and technical problems became the major constraints to realize such integration. With respect to the availability of facilities, the RTC is in good category.
\end{abstract}

Keywords: ICT integration, competency based education, Islamic education teachers.

\section{INTEGRASI TEKNOLOGI INFORMASI KOMUNIKASI DALAM DIKLAT GURU PENDIDIKAN AGAMA ISLAM (PAI)}

\begin{abstract}
Abstrak: Pentingnya pengitegrasian ICT dalam pendidikan dan pelatihan pada saat ini sudah menjadi kebutuhan mutlak. Penelitian ini menggaris bawahi peran diklat sebagai sarana untuk meningkatkan kompetensi guru PAI dalam ICT. Penelitian studi kasus ini bertujuan untuk mendeskripsikan tingkat integrasi TIK dalam diklat guru PAI dan Komunikasi (TIK) di Palembang, Indonesia. Sebanyak 30 orang guru PAI madrasah dan dua orang widyaiswara/fasilitator berpartisipasi sebagai informan. Menggunakan teknik analisis kualitatif model interaktif Miles dan Huberman, hasil penelitian menunjukan bahwa guru PAI madrasah sudah mengintegrasikan TIK namun masih terbatas pada penggunaan presentasi terutama PowerPoint. Kedua, faktor usia dan masalah teknis menjadi kendala utama dalam mengimplementasikan integrasi tersebut. Sehubungan dengan ketersediaan fasilitas TIK di BDK Palembang tergolong baik.
\end{abstract}

Kata kunci: Integrasi TIK, diklat berbasis kompetensi, guru PAI

\section{INTRODUCTION}

The development of media of information technology has become one of the main foundations in the development of $21^{\text {st }}$ century learning. Practically, IT has become something that is compulsory to our daily lives. Lets take Internet use as an example. In 2015, the number of Internet users reached 93.4 million and in 2016 it rose further to 100.1 million. Furthermore, early in 2017 there was an increase of another $51 \%$. According to results of researches conducted in Indonesia, internet users are generally dominated in number by both university-level students and students of lower levels, constituting 
respectively around $89.7 \%$ and $69.8 \%$ of the total number of Internet users in Indonesia. In addition, The National Education Standrads Board of Indonesia (BSNP) supported the goals and onbjectives of 2004 WSIS (World Summit of Information Society) conference that suggested that all universities, colleges and secondary schools across the world would have been connected to the Internet by 2015. Thus making it possible for students and teachers fromm anywhere in the world to converse, collaborate and exchange knowledge, which could improve the quality of human life.

Teachers actually have a great opportunity to utilize technology in learning. The Minister of National Education's Regulation No. 16 (2007) mentions that teachers' obligatory competence includes proficiency in the utilization of information technology for conducting educative activities of development. According to the fifth point in the sub-chapter about pedagogical competence, there is a demand that teachers are able to make use of ICT for conducting educative activities of development.

Integration of ICT in learning plays a powerful role in increasing resources and improving the environment for learning. Luhombo (2015) indicated that ICT can play a role in preparing students to acquire skills, competencies and social skills that are fundamental for competing in the emerging global "knowledge" economy. Several studies have been conducted demonstrating that an appropriate use of ICT can raise educational quality and connect learning to real-life situations (Lowther, Inan, Strahl, \& Ross, 2008; Weert \& Tatnall, 2005). As Weert \& Tatnall (2005) have pointed out, learning is an ongoing lifelong activity where learners change their expectations by seeking knowledge, which departs from traditional approaches. As time goes by, they will have to expect and be willing to seek out new sources of knowledge. ICT skills will be an indispensable prerequisite for these learners.

There is also a demand that teachers who are spearheading education should have competency in the field of ICT, as this will enable them wider opportunities (Isisag, 2012). Teachers will be able access new knowledge through ICT, integrating it into their teaching practices, whilst developing new methods and approaches (Esther, 2013; Oyarzo, 2011, Plomp, Pelgrum \& Law, 2007). ICT also enables teachers to adapt materials based on circumstances as well as students needs (Lubis, 2018).

Teachers ought to be able to transfer knowledge, attitude, behavior, and skill to their students through learning strategies and patterns that are suitable for the demands and developments of the $21^{\text {st }}$ century. Professional teachers always use creative and innovative ways in delivering knowledge, skill, and even attitude to students, which includes creativity in using learning media. The findings from Oyarzo (2011) indicated, that a teacher who can manage ICT well will become a better communicator. ICT integration helps teachers in creating interesting and enjoyable learning activities, promoting learner autonomy, and enhancing students' learning motivation (Al-Munawwarah, 2014).

Teachers as professional educators are expected to always have an open mindset and to keep developing themselves as part of the effort of preparing learners to compete in global society life. One of the solutions that could be adopted is the use of education-andtraining, which is competency-based. It is in line with Article 14 of School and University Teachers' Law' No. 14 (2005), which states that teachers have the right to access training and professional development in their field in the course of improvement in competency. Devi \& Shaik (2012) also mention that training functions as a way to make possible for human resources to show their potential. ICT professional development courses for 
teachers enables them to improve their ICT skills and knowledge (Abuhmaid, 2011). An in-depth training program acts as a tool for improving the employees' skill and making it possible for them to do their job better.

Similarly, Government Regulation No. 101 in 2000 concerning Education and Training for the Job of Civil Service Employees, states that, to form the figure of a civil service employee or civil servant, including those already in the civil service of the government, appropriate education and training are required. The process of teaching and learning in the course of improving civil servants' competency is conducted in the form of the educationand-training mentioned within the regulation. The goal is the formation of civil servants that have the competency matching the requirements for their respective jobs. The issuance of the government regulation puts emphasis on competency-based education-and-training, which surely implies that training participants, who are at the end of their education, need to be able to demonstrate certain competencies acquired when they were attending the training. This means that participants of such an education and training program should be able to show the competencies that they have gained as a direct result of the education and training received.

RTC (Religious Training Center) is a technical executive unit in the field of education and training with the main job and function of conducting education and training in accordance with the guidelines. The main job and function of RTC as written down in The Minister of Religious Affairs' Decree' No. 59 of 2015, concerning the Organization and Operating System of RTC, is conducting the education and training of the administration staff and the technical staff for religious matters according to their respective work areas. The main job of $\mathrm{BDK}$ is to give service in education and training for the staff at the Ministry of Religious Affairs, in the course of improving knowledge and skill as well as building attitudes conforming to the standard of competence that should be acquired by each staff member.

The concern of the present research is to describe the level of ICT integration into the learning conducted, based on experiences and competency in using the computer for guiding learning, the availability of ICT facilities, and ICT training attended. The research results are quite important, especially in mapping the problems faced in ICT integration into training and the alternatives for its improvement. Operationally, the main benefit obtained from this research will be the alternatives of improvement in ICT integration into training, based on the mapping of the level of ICT integration and the potential of human resources within RTC.

\section{METHOD}

The research used a qualitative method with a case-study approach. The research subjects were determined by using purposive sampling and snowball sampling. Snowball sampling was used to increase the number of the research subjects when more in-depth information was needed. The research subjects were thirty teachers of the Islamic Religious Education group of school subjects at madrasah (Islamic schools in Indonesia) and two facilitators of Palembang RTC. The demography of the participants is presented in Table 1. 
Table 1. Demography of the Participants

\begin{tabular}{llcc}
\hline \multirow{2}{*}{ Category } & Sub-category & Teachers & $\begin{array}{c}\text { Widyaiswaral } \\
\text { facilitators }\end{array}$ \\
\cline { 3 - 4 } Gender & Male & 13 & 1 \\
Age & Female & 17 & 1 \\
& $26-35$ & 11 & - \\
Teaching experiences (years) & $36-45$ & 8 & 1 \\
\multirow{3}{*}{ Classroom technology use (years) } & $46-55$ & 11 & - \\
& Below 10 years & 11 & 2 \\
& Above 10 years & 19 & - \\
& Below 5 years & 9 & 2 \\
\hline
\end{tabular}

The data were collected by means of interview, observation, and documentation. In the research, the researcher as a human instrument observed the learning process conducted in class. To confirm data validity, the validity of the research data was first examined. In the research here, to obtain comprehensive data, triangulation was used by combining all the data from various sources in various ways and at various times. Besides, to gain trustworthiness, the transcription of the questions was cross-checked by each of the participants for any mistyped words or unconfirmed ideas. The data gained was analyzed and displayed descriptively. The data was analyzed using the interactive model of qualitative analysis from Miles \& Huberman (2014). The data obtained from questions was categorized pertaining to implementation of ICT integration in Islamic Religious Education class. After the categorization process, the overall data were re-typed and displayed in the form of description. The final part consisted of the conclusion, drawing and verification, with the initial conclusion being still tentative in nature and with the potential to change when no strong evidence was found to support a following stage of data collection. The conclusion in qualitative research could answer the problem question that has been formulated since the initial part.

\section{RESULT AND DISCUSSION Result}

The first indicator refers to experience and competence in computer use in conducting learning. The results indicate that not all of the respondents have been accustomed to integrating ICT as a learning media (one of the ICT materials in this training is how to make powerful PowerPoint). Interestingly, only eleven of the thirty respondents employ PowerPoint and none of them use email, blog or website as the learning media in the Islamic Religious Education class. Thus, in general the use of and training in ICT would be considered beneficial for Islamic Religious Education teachers. According to results of interviews with two widyaiswaras/facilitators at Palembang RTC and seven participants, the lack of teachers' competence in utilizing various ICT facilities made available by RTC staff is also a result of age factor, as presented in Table 2.

Means and resources directly play important roles in the educational world, in order to support the attainment of educational objectives in general and particularly to the integration of ICT into learning. The means and resources should also be continuously developed for the success of the educational process at RTC. Projectors in every classroom and Internet access are compulsory resources that RTC should provide. ICT resources form some of the important elements in educational 
supplies and should therefore keep up with the increasingly faster technological development. Based on the data obtained during the research, the various means and resources supporting the utilization of ICT in the learning process are presented in Table 3 below.

\section{Table 2. The Result of Interview with Respondents}

\begin{tabular}{|c|c|}
\hline Indicator & Interview Result \\
\hline $\begin{array}{l}\text { 1. Participants' competence } \\
\text { in computer utilization }\end{array}$ & $\begin{array}{l}\text { - The teacher who is already aged has difficulty in keeping up } \\
\text { with the fast flow of ICT development, which in the end makes } \\
\text { the said teacher helplessly overwhelmed in utilizing the device } \\
\text { used to give support to the material taught. } \\
\text { - Teachers tend to only be able to use the PowerPoint computer } \\
\text { program in their teaching process. } \\
\text { - The teachers attending training at RTC do not yet use e-mail, } \\
\text { blog or a website as a system to conduct learning. } \\
\text { - Lack of computer skills } \\
\text { - Limited knowledge of operating ICT } \\
\text { - Lack of ICT-based materials }\end{array}$ \\
\hline 2. Availability of facilities & $\begin{array}{l}\text { - A technical problem here is the unstable condition of the } \\
\text { Internet network, which unfortunately has a negative impact on } \\
\text { the planning already completed by facilitators trying to conduct } \\
\text { learning through the use of ICT. Although the whole area of } \\
\text { RTC is already covered by the wireless hotspot facility, at } \\
\text { times it is still not possible to get connected to the Internet } \\
\text { network. }\end{array}$ \\
\hline $\begin{array}{l}\text { 3. Facilitators and ICT } \\
\text { training program }\end{array}$ & $\begin{array}{l}\text { - There are four types of training that have been attended by } \\
\text { training participants. The following is a list of the four types of } \\
\text { training mentioned in order from those most frequently } \\
\text { attended. (A) basic computer use, (B) ICT-based learning } \\
\text { innovation, (C) presentation media (still restricted to } \\
\text { PowerPoint) and (D) the Internet. Most of the training } \\
\text { participants state that they have attended all four types of } \\
\text { training. }\end{array}$ \\
\hline
\end{tabular}

Tabel 3. Internet Facilities

\begin{tabular}{llll}
\hline No & Types of equipment & Total \\
\hline & Desktop Computer & 64 & units \\
& Notebook/Laptop (widyaiswara/fasilitator) & 53 units \\
Internet access & up to 13 Mbps \\
LAN (WIFI) & 9 & units \\
Sound System & 13 & units \\
Intercatif board & 5 & units \\
Server computer & 3 & units \\
Kamera Digital & 2 & units \\
Handycam & 1 & unit \\
Television & 7 & units \\
LCD/LED & 10 & units \\
Computer \& Multimedia laboratory & 1 & room \\
Computer \& Multimedia laboratory & 13 & points \\
\hline
\end{tabular}


Other supporting means and resources for quality improvement in education and learning are computers and Internet access. Such resources are expected to raise extrinsic motivation that improve the learning and motivation of facilitators and learners, especially with the Internet exerting great influence in the world of education. Its right utilization will overcome shortcomings, which have constrained the learning process. The Internet provides information of a broad scope and facilitates communication, discussion, and question-and-answer sessions that help overcome the difficulties undergone by learners.

The third indicator deals with the types of ICT training attended by the training participants. Based on the interview results, there are four types of training that have been attended by training participants. The four types of training, mentioned in order from the most frequently attended to the least frequently attended are, (A) basic computer use, (B) ICT-based learning innovation, (C) presentation media (still restricted to PowerPoint), and (D) the Internet. Most of the training participants state that they have attended all four types of training.

\section{Discussion}

As reflected from the aforementioned findings, the majority of the respondents have experience of using some types of ICT as a learning media in Islamic Religious Education class. This is in line with what Claro (2010) found, that ICT can be used to improve the teaching and learning process. Furthermore, UNESCO (2002b) states that the utilization of ICT in the learning process has three main objectives, namely: to build up knowledge in problem solving and competence in communication, and in seeking, processing or managing information, transforming it into new knowledge and disseminating it to others; to develop skills in using ICT; and to improve effectiveness and efficiency in learning. ICT is a powerful tool to utilize 21st century skills (Pearlman, 2010). Integration of ICT into teaching and the learning process will empower teachers to focus on: student-centered approach; active and interactive learning; connecting with learner experiences and needs; and the development of critical and ethical understandings of the value in using ICT (Ministerial Council on Education, Employment, Training and Youth Affairs, 2005). So, it is considered that these types of ICT are extremely beneficial. Another reason is also its ability to enrich faciliators teaching materials.

Additionally, the barriers to ICT integration are most frequently limited facilities, lack of skills in operating ICT equipment and limited ICT-based material. Similarly, research conducted by AlMunawwarah (2014), Honan (2008), and Lubis (2018) found that age, lack of computer skills, limited knowledge and experience of ICT, lack of ICT-based materials, time allocation and technical problems became the major challenges for teachers. Another obstacle experienced in the use of ICT in RTC is that this is only training, so after the completion of the education and training process, participants must return to their respective work units. This resulted in a disconnection between the widyaiswara/facilitator and the training participants. In a sense, a widyaiswara/facilitator does not have the authority to monitor the training alumni. Likewise, vice versa, the alumni were already busy with their respective activities.

Apparently, the teachers have not given a considerable look to the use of the social networking site as a learning system. The reason is that there are still many teachers who have not yet attempted to begin utilizing the social networking site as one of the alternative learning strategies. Social networking sites that are familiar in teachers' circles have the potential for being utilized as means of 
learning to replace the function of the learning management system software. Compared with the learning management system software, the social networking site has an advantage because it can be used without having to rent or manage a server, and most importantly, it is more familiar among training participants.

In relation to the facilities, the findings indicate that RTC has supported the integration of ICT into the teaching and learning process. All of the classes have already had access to the means and resources related to the ICT integration (Table 2). However, the Internet access was still limited, despite wireless hotspot in the whole area of RTC.

The last indicator reveals the types of training in ICT that have been attended by training participants. More similar training is needed to accommodate teachers who have not been able to integrate ICT into their learning (teaching)? So that they are better prepared to keep up with the advancement of technology. One finding of the Pelgrums \& Law study (2003), was that there were not enough training opportunities for teachers in the use of ICTs in a classroom environment. Similarly, Beggs (2000) found that one of the top three barriers to teachers use of ICT when teaching students was the lack of training. Recent research in Turkey found that the main problem with the implementation of new ICT in science was the insufficient amount of in-service training programs for science teachers (Özden, 2007), and Toprakci (2006) concluded that limited teacher training in the use of ICT in Turkish schools is an obstacle.

Based on the findings, it is important to pay attention to the management in conducting the training in order to maintain quality assurance, consisting of conformity among the material, the media, the instructor/facilitator, and the required facilities. Well-managed trainings will help to assure good final outcomes.
Furthermore, conducting training is inseparable from program manager and facilitator. The program manager could be someone from inside the organization conducting the training (such as a school) or someone from outside. The program manager's function is identifying participants and the material needed. A training program also requires a facilitator as the expert that can help teachers to overcome problems in integrating ICT into learning and any problems related to the hardware and software used (Tong \& Triniada, 2005). A facilitator can be someone who is originally a teacher of Computer Skills and Information Management at a school, or a person considered to have experience and capability concerning the training material (Abuhmaid, 2011; Singh \& Samili, 2014; Samuel \& Zaitun, 2007).

According to the head of the section of technical staff for education and religion at Palembang RTC, and are not yet based on an analysis of need. Therefore, within a one-year period, most teachers attend only one ICT training activity.

ICT training programs could improve teacher competence in computer use (Uslu, 2012; Abuhmaid, 2011). Training plays an important role in a teachers readiness to use computers (Gan, 2001). It could also improve teachers' attitude in computer utilization (Keengwe \& Onchwari, 2008), and aid teachers in improving learning activity and in turn the learning conducted should improve the quality of education (Parvin, 2013). ICT trainings could become the teachers' media for the improvement of their competence in the integration of ICT. Studies reveal that training good quality programs aid teachers in integrating ICT into learning and applying change into the teaching practice (Brinkerhoff, 2006). Lawless \& Pellegrino (2007) state that if the training program is of high quality, lasts for a longer period, is supported by new technology, provides a good supportive training climate, and states a 
clear vision for learners' achievement; then the teachers would be able to adopt and integrate ICT into their teaching. Furthermore, ICT related training programs develop teachers' competences in computer use (Bauer \& Kenton, 2005; Wozney, Venkatesh, \& Abrami, 2006).

According to Chen (2008), professional training programs should be designed for identifying beliefs about successful teaching, improved teaching policies, and a syllabus that is designed in relation with the teaching objective. The minimum frequency of effective training becomes one of the greatest hindrances that are often encountered in the field (Özden, 2007; Albrini, 2006). Ivancevich (2007) acknowledges that training is a systematic process which is used to change trainees' behavior, directed to the attainment of an organization's objective, related to work skill and competence, and oriented to aiding the trainees in mastering specific skill and competence.

The execution of a learning program utilizing ICT is sure to bring to those in RTC's part, the challenge of a more optimal ICT utilization in the learning conducted. Various efforts to progress the teaching staff's professional competence are continuously made, such as, improvement in developing more creative material for the learning assigned. Therefore, the facilitator should always keep up with the current technological development.

Based on the results of the research conducted, Palembang RTC has taken various steps in an effort to optimize ICT utilization in the learning conducted. First, RTC conducted various programs and strategies to complete the ICT-based means and resources. For example, all classrooms are presently equipped with LCD, the bandwidth of the Internet access is increased, and other ICT-based equipment are made available. RTC also provides a laptop for facilitators who do not have a laptop. Palembang RTC also conducts long-distance training (with distance learning) as one of the effective ways to integrate ICT. Additionally, Palembang RTC has developed Simtraining, an application that is used not only for participants' online registration but also for providing data in accordance with Minister of Religious Affairs' regulation.

\section{CONCLUSION}

This research was aimed at finding out the ICT integration into Islamic religious education teacher training. First, ICT learning is not yet fully implemented in the training conducted by RTC. Secondly the participants' paradigm when utilizing ICT in learning is still restricted to giving presentations, particularly using the PowerPoint computer program. Internet use is still restricted to finding additional information concerning the material to be delivered, instead of making it a part of a new learning system strategy, which is integrated into the learning process conducted; likewise, the social networking site is still not yet well utilized as a part of the learning system.

Thirdly, the training participants' professionalism can still be considered as the main hindrance, which is troubling, especially when faced with other technical hindrances, such as financing and Internet connectivity.

In relation to training participants' intensity in attending ICT training, it can be concluded that the involvement of training participants in ICT training is lacking. The reason is that the training held by RTC of Palembang is minimum in quantity and frequency. On average, the training participants attend ICT training only once a year.

However, the main supporting factor is the availability of various ICT facilities and resources that are sufficient enough for the use of ICT in teaching and learning.

\section{REFERENCES}

Abuhmaid, A. (2011). ICT training courses for teacher professional 
development in Jordan. The Turkish Online Journal of Educational Technology, 10(4), 195-210.

Albrini, A. (2006). Teachers attitudes toward information and communication technologies: The case of Syrian EFL teachers. Computers \& Education, 47(4), 373398. doi: 10.1016/j.compedu.2004.10.013.

Al-Munawwarah, S. F. (2014). Teachers' perceptions on the use of ICT in Indonesian EFL learning context. English Review: Journal of English Education, 3(1), 70- 80. Retrieved from

https://journal.uniku.ac.id/index.php/ ERJEE.

Bauer, J., \& Kenton, J. (2005). Toward technology integration in the schools: Why it isn 't happening. Journal of Technology and Teacher Education, 13(4), 519-546. from https://www.learntechlib.org/pr imary/p/4728/.

Beggs, T. A. (2000, April 9-11). Influences and barriers to the adoption of instructional technology. Paper presented at the Proceedings of the Mid-South Instructional Technology Conference, Murfreesboro, TN. Retrieved from https://eric.ed.gov/?id=ED446764.

Brinkerhoff, J. (2006). Effects of a long duration, professional development academy on technology skills, computer selfefficacy and technology integration beliefs and practices. Journal of Research on Technology in Education, 39(1), 22-43.

doi:

10.1080/15391523.2006.10782471.

Chen, C. H. (2008). Why do teachers not practice what they believe regarding technology integration? The Journal of Educational Research, 102(1), 65-75. doi: 10.3200/JOER.102.1.65-75.

Claro, M. (2010). Proposals for a conceptual framework and list of 21 st century competencies for the development of an evaluation system of ICT competencies for the 21st century for 15 year old Chilean students. Santiago: MS. (Chapter 1).

Devi, R. \& Shaik, N. (2012). Evaluating training \& development effectiveness: A measurement model. Asian Journal of Management Research, 2(1), 722-735. Retrieved from http://ipublishing.co.in/.

Esther, A. F. (2013). Information and communication technology as teaching and learning space for teachers English language in schools. Journal of Emerging Trends in Educational Research and Policy Studies, 5(1), 100-107.

Gan, S. L. (2001). IT \& education in Malaysia: Problem, issues and challenges. Petaling Jaya: Pearson Education.

Honan, E. (2008). Barriers to teachers using digital texts in literacy classrooms. Literacy, 42(1), 36-43. doi: $\quad 10.1111 / \mathrm{j} .1467-$ 9345.2008.00480.x.

Isisag, K. U. (2012). The positive effects of integrating ICT in foreign language teaching. Paper presented in International Conference ICT for Language Learning (5th Ed). Retrieved from https://conference.pixel-online.net

Ivancevich, J. M. (2007). Human resource management (10th ed). New York, NY: McGraw-Hill. 
Kandasamy, M., \& Shah, P. Bt. M. (2013). Knowledge, attitude and use of ICT among ESL teachers. GSE Journal of Education, 185-199. Retrieved from https://worldconferences.net.

Keengwe, J. \& Onchwari, G. (2011). Computer technology integration and student learning: barriers and promise. Journal of Science Education and Technology, 17(6), 560-570. Retrieved from https://eric.ed.gov/?id=EJ818933.

Lawless, K., \& Pellegrino, J. (2007). Professional development in integrating technology into teaching and learning: Knowns, unknowns and ways to pursue better questions and answers. Review of Educational Research 77(4), 575-614. doi: 10.3102/0034654307309921.

Lowther, D. L., Inan, F. A., Strahl, J. D. \& Ross, S. M., (2008). Does technology integration work when key barriers are removed? Educational Media International, 45(3), 195-213. Retrieved from https://www.learntechlib.org/p/1015 $34 /$.

Lubis, A. H. (2018). Integrasi TIK dalam pengajaran bahasa Inggris di Indonesia abad ke-21: mitos dan realita. Cakrawala Pendidikan, 37(1), 11-21. doi: 10.21831/cp.v37il.16738.

Luhombo, C. S. (2015). Teacher factors influencing integration of ICT in teaching of English in public secondary school in Mumias SubCounty Kenya. Unpublished Research Project. University of Nairobi, Kenya: University Press.

Miles, M. B \& Huberman, A. M. (2014). Analisis data kualitatif.
Jakarta: Universitas Indonesia (UIPress).

Ministerial Council on Education, Employment, Training and Youth Affairs. (2005). Pedagogy Strategy: Learning in an online world. Carlton South, Australia: MCEETYA.

Oyarzo, P. F. (2011). Competencies for the 21st century: Integrating ICT to life, school and economical development. Procedia-Social and Behavioral Sciences 28(2011), 54-57. doi: 10.1016/j.sbspro.2011.11.011.

Özden, M. (2007). Problems with science and technology education in Turkey. Eurasia Journal of Mathematics, Science, \& Technology Education, 3(2), 157-161. Retrieved from http://www.ejmste.com.

Parvin, M. S. (2013). Integrations of ICT in education sector for the advancement of the developing country: Some challenges and recommendations-Bangladesh perspective. International Journal of Computer Science \& Information Technology (IJCSIT), 5(4), 81-92. doi: 10.5121/ijcsit.2013.5406.

Pearlman, B. (2010). Designing new learning environment to support 21 st century skills. 21st century skills: Rethinking how students learn. Bloomington, IN: Solution Tree Press.

Pelgrum, W. J., \& Law, N. (2003). ICT in Education around the world: Trends, problems and prospects. Paris: UNESCO-International institute for educational planning.

Plomp, T., Pelgrum, W. J., \& Law, N. (2007). SITES2006-International comparative survey of pedagogical practices and ICT in education. Education and Information 
Technologies, 12(2), 83-92. doi: 10.1007/s10639-007-9029-5.

RoI, Law 2005 No. 14, Teacher and Lecturer.

RoI, Govermental Regulation 2000 No. 101, Civil Servants Education and Training.

RoI, Ministrial Regulation of National Education 2007 No. 16, Academic Qualification Standards and Teacher Competencies.

RoI, Ministrial Regulation of Religion 2015 No. 59, Organization of Work Procedures for the Religious Education and Training Center.

Samuel, R. \& A. Zaitun. (2007). Do teachers have adequate ICT resources and the right ICT skills in intergrating ICT tools in the teaching and learning of english language in Malaysia schools? The Electronic Journal of Information Systems in Developing Countries, 29(2), 1-15. doi: $10.1002 / \mathrm{j} .1681-$ 4835.2007.tb00196.x.

Singh, T. K. R. \& Samili, C. (2014). Teacher readiness on ICT integration in teaching-learning: A Malaysian case study. International Journal of Asian Social Science, 4(7), 874-885. Retrieved from http://www.aessweb.com.

Tong, K. P., \& Triniada, S. G. (2005). Conditions and constraints of sustainable innovative pedagogical practices using technology. Journal of International Electronic for Leadership in Learning, 9(3), 1-27.

Toprakci, E. (2006). Obstacles at integration of schools into information and communication technologies by taking into consideration the opinions of the teachers and prin cipals of primary and secondary schools in Turkey. Journal of Instructional Science and Technology (e-JIST), 9(1), 1-16. Retrieved from http://ascilite.org.

UNESCO. (2002b). Toward policies for integrating ICTs into education. Retrieved from http://www. unescobkk.org/.

Uslu, O. (2012). Effects of the professional development program on turkish teachers: Technology integration along with attitude towards ICT in education. The Turkish Online Journal of Educational Technology, 11(3), 115127. Retrieved from https://eric.ed.gov/?id=EJ989205.

Weert, T. V. \& Tatnall, A., (2005). Information and communication technologies and real-life learning: New education for the new knowledge society. New York: Springer.

Wozney, L., Venkatesh, V., \& Abrami, P. C. (2006). Implementing computer technologies: Teachers' perceptions and practices. Journal of Technology and teacher education, 14(1), 173207.

Retrieved from https://www.learntechlib.org/pr imary/p/5437/. 